ScIDice

\section{A Comparative Evaluation Of The Canal Centering Ability Of Three Rotary File Systems: An In Vitro Study}

Research Article

Krisha Doshi ${ }^{1}$, S. Delphine Priscilla Antony ${ }^{2 *}$, M.S.Nivedhitha ${ }^{3}$

${ }^{1}$ Department of Conservative Dentistry and Endodontics, Saveetha Dental College, Saveetha Institute of Medical and Technical Sciences, Saveetha University, Chennai - 600077, India.

${ }^{2}$ Senior lecturer, Department of Conservative Dentistry and Endodontics, Saveetha Dental College, Saveetha Institute of Medical and Technical Sciences, Saveetha University, Chennai- 600077, India.

${ }^{3}$ Professor and Head of the Department, Department of Conservative dentistry and Endodontics, Saveetha Dental College and Hospitals, Saveetha Institute of Medical and Technical Sciences, Saveetha University, Chennai- 600077, India.

\title{
Abstract
}

Background: Canal centering is the ability of the instrument to stay centered within the root canal. This prevents canal transportation, perforation, preserves dentin and increases strength of the tooth. Recent NiTi endodontic file systems are manufactured with heat treatment technology that improves the canal centering ability of these files.

Aim: To compare the canal centering ability of Protaper Gold, Hyflex CM and Profile S3 endodontic file systems using cone beam computed tomography.

Materials and Methods: Thirty mesial root canals in fifteen extracted mandibular molars were included in the study. Access cavities were prepared and WL was established. The canals were divided into 3 groups ( $n=10)$ : Group 1 - Protaper Gold (PTG); Group 2 - ProFit S3 (PS3); Group 3 - Hyflex CM (HCM). Pre and post-instrumentation CBCT was taken. The canal centering ability was assessed at 3,6 and $9 \mathrm{~mm}$ from the root apex. Statistical analysis was done using ANOVA and post hoc Tukey test.

Results: The mean canal centering ratio for PTG at $3 \mathrm{~mm}$ was $1.85 \mathrm{~mm}$, at $6 \mathrm{~mm}$ was 1.53 and at $9 \mathrm{~mm}$ was $1.9 \mathrm{~mm}$. That for Profit S3 was 1.6, 1.49 and 1.6mm respectively; while for Hyflex CM was 1.6, 1.56 and $1.71 \mathrm{~mm}$ respectively. There was no statistical difference at any level between any of the groups $(\mathrm{p}>0.05)$.

Conclusion: All the file systems remained relatively centralized within the root canal. Hence they can be used in curved canals without fear of canal transportation or straightening.

Keywords: Centering Ability; Protaper Gold; Hyflex CM; Profile S3; Cone Beam Computed Tomography.

\section{Introduction}

The primary goal of endodontic therapy is the complete disinfection of the root canal space followed by a three-dimensional apical and coronal seal [1]. This is preceded by a proper biomechanical root canal preparation. An ideal preparation must maintain the original root canal anatomy as far as possible. According to Schilder's principle [2], a prepared canal must be continuously tapered preparation that maintains the canal anatomy, keeping the foramen as small as possible, without any deviation from the original canal curvature.
Root canal anatomy is quite unpredictable, especially the apical one-third. Canal anatomy is varied and curvatures can begin at any level within the canal space [3]. Maintaining a centered preparation is difficult in such curved and flattened canals due to their complex internal anatomy. Inability to do so may lead to excessive and inappropriate dentin removal [4], straightening of the canal and ledge formation, elbow formation, hourglass preparations, and over-preparation [5]. Mesial root canals of mandibular first molars are reported to be curved both in buccolingual and mesiodistal directions [6]. Maintaining a centered preparation is dif-

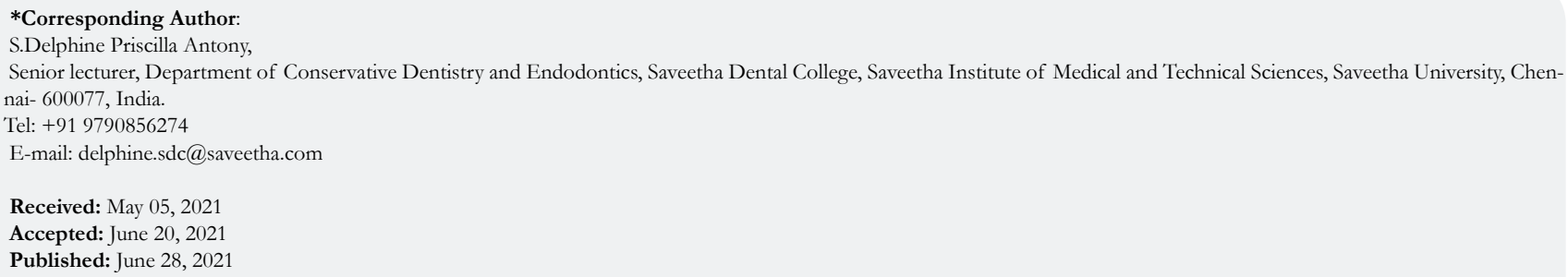

Copyright: S.Delphine Priscilla Antony ${ }^{\circ} 021$. This is an open-access article distributed under the terms of the Creative Commons Attribution License, which permits unrestricted use, distribution and reproduction in any medium, provided the original author and source are credited. 
ficult and hence these teeth are more prone to ledging and canal transportations.

With the advent of nickel-titanium instruments in endodontics, root canal preparations have become easier and more predictable. Nickel-titanium files are known for their elasticity and resistance to torsional fatigue when compared to hand stainless steel files [7]. Several types of thermal treatments have been developed with the aim of optimizing the mechanical properties of NiTi alloy [8, 9]. Some of them include $M$ wire technology, R-phase, controlled memory, gold files, blue files, etc. They are known to have better flexibility, fracture resistance, resistance to cyclic fatigue, etc.

Protaper Gold files were developed with advanced metallurgy and have a progressively tapered design that is claimed by the manufacturer to enhance cutting efficiency and safety. These files have a convex triangular cross-section and a progressive taper, hence the name 'Protaper'. The manufacturer claims that this property helps in navigating challenging curves in the apical region of the canal while giving a proper shape to the canal. The file also has a feature of a shorter handle for improved accessibility to the teeth $[10]$.

'Hyflex CM' is a NiTi rotary file system made using the novel "controlled memory" technology. Controlled memory wire (CM wire) is manufactured by a unique process that controls the material's memory, making the files extremely flexible, but without the shape memory that is typical of other NiTi files. The file maintains the shape of the canal even after its removal. This prevents canal straightening and hence it is widely used in curved canals [11].

ProFit S3 (PS3) is a new endodontic file system introduced in the year 2019. It is a blue file manufactured using new heat-treated technology. This rotary system has a titanium oxide coating and hence the blue color. It has a variable taper design, which varies between $4 \%$ and $8 \%$, with a rectangular cross-section. In crosssection, the file makes a two-point contact with the canal walls, thereby reducing the apical extrusion of debris. PS3 has good shape memory, flexibility, and increased resistance to fracture. [12].
Cone-beam computed tomography is a non-invasive, three-dimensional imaging tool that has been advocated for pre and postinstrumentation canal evaluation. It allows for an accurate comparison of endodontic instrumentation at different levels in the root canal [13]. Because of both its accuracy and the possibility to preserve the tooth structure, CBCT has been increasingly used to evaluate apical transportation and centralization.

Hence, the aim of the study was to compare the canal centering ability of Protaper Gold, Profit S3, and Hyflex CM rotary file systems using CBCT.

Previously our team has a rich experience in working on various research projects across multiple disciplines [14-28] Now the growing trend in this area motivated us to pursue this project.

\section{Materials And Methods}

Thirty mesial root canals in Vertucci's Type IV configuration in fifteen extracted mandibular molars with fully developed roots were included in the study. The teeth exhibited no defects, their root canals were not calcified, showed no internal or external root resorption, no prosthetic crowns or dental posts, no signs of prior endodontic treatment, and no aberrant canal morphology. Only teeth with apical curvature between 20 and 40 degrees were included. The teeth were mounted on wax models (Figure 1) and preoperative CBCT was taken.

The access cavity was prepared using Endo Access bur, $21 \mathrm{~mm}$ size 2 (Dentsply Maillefer, Swiss made) and K-file (Mani, Utsunomiya, Tochigi, Japan) of size \#10 hand files were used to achieve the initial patency of the canal to full working length (WL), visible at the apical foramen, and the WL was established $1 \mathrm{~mm}$ short of this length. The canals were randomly divided into 3 groups $(\mathrm{n}=10)$ : Group 1 - Protaper Gold (PTG); Group 2 - ProFit S3 (PS3); Group 3 - Hyflex CM (HCM). Instrumentation was done using the file systems of the respective groups and post-operative CBCT was taken.

The canal centering ability was assessed at 3, 6, and $9 \mathrm{~mm}$ from the root apex. The following formula was used the calculate the canal centering ability:

Figure 1: Demonstrating teeth mounted on wax models.

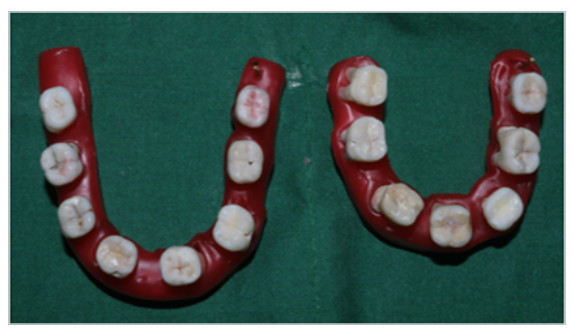

Figure 2: Demonstrating pre and post-instrumentation CBCT images and showing a1, b1, a2 and b2..

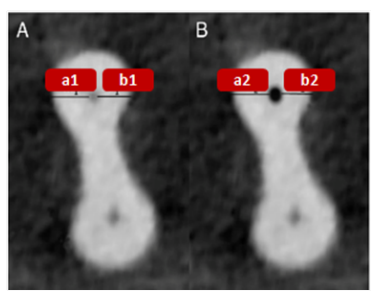


$(\mathrm{a} 1-\mathrm{a} 2) /(\mathrm{b} 1-\mathrm{b} 2)$ or $(\mathrm{b} 1-\mathrm{b} 2) /(\mathrm{a} 1-\mathrm{a} 2)$; where $\mathrm{a} 1$ and $\mathrm{b} 1$ the shortest distance from the mesial edge of the root to the mesial edge of the uninstrumented canal and the shortest distance from the distal edge of the root to the distal edge of the uninstrumented canal. a2 and b2 the shortest distance from the mesial edge of the root to the mesial edge of the instrumented canal and the shortest distance from the distal edge of the root to the distal edge of the instrumented canal (Figure 2). According to this formula, a result of ' 1 ' indicates perfect centering.

The data were evaluated statistically using SPSS software (Version 23.0) by one-way analysis of variance (ANOVA) followed by the post hoc Tukey test to explore canal centering ability in each group. The level of significance was set at 0.05 .

\section{Results And Discussion}

Table 1 shows the centering ratio values at 3,6, and 9mm levels for the three groups. The mean canal centering ratio for PTG at 3 $\mathrm{mm}$ was $1.85 \mathrm{~mm}$, at $6 \mathrm{~mm}$ was 1.53 and at $9 \mathrm{~mm}$ was $1.9 \mathrm{~mm}$. The mean canal centering ratio for Profit S3 at $3 \mathrm{~mm}$ was $1.6 \mathrm{~mm}$, at 6 $\mathrm{mm}$ was 1.49 and at $9 \mathrm{~mm}$ was $1.6 \mathrm{~mm}$. The mean canal centering ratio for Hyflex $\mathrm{CM}$ at $3 \mathrm{~mm}$ was $1.6 \mathrm{~mm}$, at $6 \mathrm{~mm}$ was 1.56 and at $9 \mathrm{~mm}$ was $1.71 \mathrm{~mm}$. The mean canal centering ratio showed no statistical difference at any level between any of the groups $(\mathrm{p}>0.05)$ (Table 2, Figure 3).

In this study, the canal centering ability of three brands of rotary endodontic file systems namely, Protaper Gold, Profit S3, and Hy-

Figure 3: Bar graph representing the mean canal centering ratios for each group at 3, 6 and $9 \mathrm{~mm}$ levels. No statistically significant difference observed between any of the groups at any of the levels $(\mathrm{p}>0.05)$.

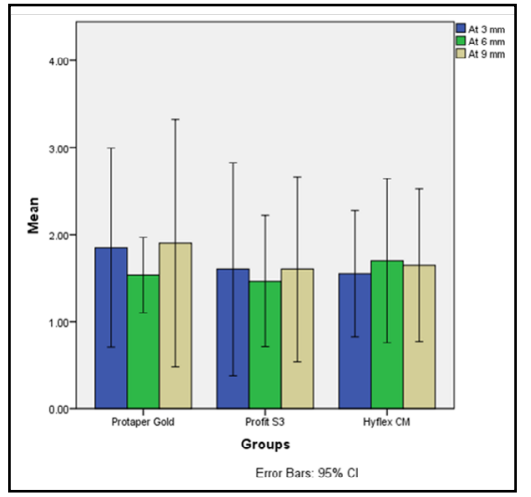

Table 1: Representing the Mean Canal Centering Ratios for the three file systems at 3, 6, and 9mm levels.

\begin{tabular}{|c|c|c|c|c|}
\hline \multicolumn{2}{|c|}{ Groups } & At 3 mm & At $\mathbf{6 ~ m m}$ & At 9 mm \\
\hline PTG & Mean & 1.85 & 1.535 & 1.9 \\
\cline { 2 - 5 } & Std. Deviation & 1.599 & 0.606 & 1.983 \\
\hline \multirow{2}{*}{ PS3 } & Mean & 1.6 & 1.466 & 1.6 \\
\cline { 2 - 5 } & Std. Deviation & 1.713 & 1.057 & 1.487 \\
\hline \multirow{2}{*}{ HCM } & Mean & 1.55 & 1.7 & 1.65 \\
\cline { 2 - 5 } & Std. Deviation & 1.012 & 1.317 & 1.226 \\
\hline Total & Mean & 1.667 & 1.567 & 1.717 \\
\cline { 2 - 5 } & Std. Deviation & 1.428 & 1.004 & 1.546 \\
\hline
\end{tabular}

Table 2: Comparing the centering ability between groups by ANOVA and post hoc Tukey tests of significance. No statistically significant difference observed between any of the groups $(\mathrm{P}>0.05)$.

\begin{tabular}{|c|c|c|c|c|c|}
\hline $\begin{array}{l}\text { Dependent } \\
\text { Variable }\end{array}$ & (I) Groups & (J) Groups & $\begin{array}{c}\text { Mean Difference } \\
\text { (I-J) }\end{array}$ & $\begin{array}{l}\text { Std. Er- } \\
\text { ror }\end{array}$ & Sig. \\
\hline \multirow[t]{6}{*}{ At $3 \mathrm{~mm}$} & \multirow[t]{2}{*}{ Protaper Gold } & Profit S3 & -0.23 & 0.275 & 0.685 \\
\hline & & Hyflex CM & -0.18 & 0.275 & 0.792 \\
\hline & \multirow[t]{2}{*}{ Profit S3 } & Protaper Gold & 0.23 & 0.275 & 0.685 \\
\hline & & Hyflex CM & 0.05 & 0.275 & 0.982 \\
\hline & \multirow[t]{2}{*}{ Hyflex CM } & Protaper Gold & 0.18 & 0.275 & 0.792 \\
\hline & & Profit S3 & -0.05 & 0.275 & 0.982 \\
\hline \multirow[t]{6}{*}{ At $6 \mathrm{~mm}$} & \multirow[t]{2}{*}{ Protaper Gold } & Profit S3 & 0.64 & 0.389 & 0.244 \\
\hline & & Hyflex CM & -0.37 & 0.389 & 0.613 \\
\hline & \multirow[t]{2}{*}{ Profit S3 } & Protaper Gold & -0.64 & 0.389 & 0.244 \\
\hline & & Hyflex CM & $-1.01000^{*}$ & 0.389 & 0.039 \\
\hline & \multirow[t]{2}{*}{ Hyflex CM } & Protaper Gold & 0.37 & 0.389 & 0.613 \\
\hline & & Profit S3 & $1.01000^{*}$ & 0.389 & 0.039 \\
\hline \multirow[t]{6}{*}{ At $9 \mathrm{~mm}$} & \multirow[t]{2}{*}{ Protaper Gold } & Profit S3 & -0.872 & 0.407 & 0.1 \\
\hline & & Hyflex CM & -0.477 & 0.407 & 0.479 \\
\hline & \multirow[t]{2}{*}{ Profit S3 } & Protaper Gold & 0.872 & 0.407 & 0.1 \\
\hline & & Hyflex CM & 0.395 & 0.407 & 0.601 \\
\hline & \multirow[t]{2}{*}{ Hyflex CM } & Protaper Gold & 0.477 & 0.407 & 0.479 \\
\hline & & Profit S3 & -0.395 & 0.407 & 0.601 \\
\hline
\end{tabular}


flex CM, was assessed at 3, 6, and $9 \mathrm{~mm}$ from the apex. All the canals were enlarged up to a tip diameter of $0.25 \mathrm{~mm}$ and a taper of $6 \%$. The lower the value in the centering ratio indicated the preparation was centered in the canal. There was no statistical difference among the three groups $(\mathrm{P}>0.05)$, indicating that all three file systems were well centered in the root canal at 3, 6, and 9 $\mathrm{mm}$ from the root apex. This can be related to instrument manufacturing, all three systems are heat-treated file systems, making it more flexible and less straightening within the canals during instrumentation.

A number of factors are known to influence the canal centering ability of endodontic files. They include; alloy used, cross-section, taper, tip design, etc [29]. In general, NiTi files with the less crosssectional area and taper, and with a non-cutting tip show better canal centering ability.

The cross-section of PTG files is convex triangular, PS3 is offset rectangular and Hyflex CM is double fluted. All the files have a non-cutting tip. The PS3 and PTG both have a variable taper and both are heat-treated file systems, the difference is that PTG has a sequence of instruments to be used and whereas PS3 is a single file system [12].

A previous study by Arslan et al. in 2017, concluded that there was no significant difference among Protaper Gold, ProTaper Universal, and Reciproc file systems when tested for centering ratio at 3 $\mathrm{mm}, 5 \mathrm{~mm}$, and $7 \mathrm{~mm}$ from the apical terminus of the root [30]. A study by Iqbal et al. [31] compared the apical transportation between the ProFile and ProTaper instruments. They stated that the variable taper design of Protaper dampens the screw-in effect. Thus, a simpler convex triangular design, as seen in the case of Protaper, is capable of performing equally well or slightly better than ProFile. A comparative study by Guelzow et al, of six rotary Ni-Ti systems (Flexmaster, System Gt, HERO 642, K3, ProTaper, and Race) showed that ProTaper instruments created more regular and uniform canal diameters [32]. Conversely, Yoshmine et al. [33] compared the shaping effects of three Ni-ti rotary instruments: ProTaper, K3, \& RaCe, in simulated S-shaped canals. They proved that the ProTaper files caused significantly greater canal widening, especially on the concave aspect of the curve, tending towards straightening of the canal, whereas the $\mathrm{K} 3$ and $\mathrm{RaCe}$ groups showed no indication of deviation.

A similar study on the Profit S3 system evaluated the canal transportation, centering ability and RDT of PS3 with PTG and OneCurve systems. They concluded that no significant difference was observed between the three systems in terms of canal centering ability [12]. The cross-section of the PS3 system is similar to the Protaper Next system having an offset rectangular cross-section with a two-point contact. A study by Mamede-Neto et al, 2017 stated that there was no significant difference between the canal centering ability of Protaper Gold and Protaper Next files [34].

Tirthankar et al [35] assessed the canal centering ability of ProtaperNext, Hyflex CM and Twisted files in mandibular molars and concluded that Twisted files had the best centering ratios followed by Hyflex CM and finally Protaper Next. Kishore et al [36] compared Hyflex CM, Twisted files, and Wave One files and concluded that Hyflex CM showed the best canal centering ability and the least canal transportation. Although this study made use of $4 \%$ taper of Hyflex CM and stated that the better results may be attributed to this lesser taper used.

NiTi rotary file systems have brought about a massive improvement in endodontics in terms of speed, shaping ability, reduced operator fatigue, etc. With the developing technology used to manufacture these new-age file systems, the error rates have dropped to almost negligible. Although a number of in vitro researches are being done testing these instruments, long term clinical studies on the outcome, success and survival of the treated teeth are more desirable.

Our institution is passionate about high quality evidence based research and has excelled in various fields $[10,37,46]$.

\section{Conclusion}

In conclusion, this in vitro study showed that all the NiTi rotary systems investigated were safe to use, as they remained relatively centralized within the root canal. Hence they can be used even in curved canals without the fear of canal transportation or straightening. Further studies should be conducted to replicate these findings in real clinical situations.

\section{Acknowledgement And Declarations}

The authors would like to acknowledge the institution and all the staff members of the Department of Conservative Dentistry and Endodontics for their support towards completion of this research. The authors deny any conflicts of interest associated with this paper.

\section{References}

[1]. Ingle JI, Baumgartne JC. Ingle's endodontics 6. BC Decker; Maidenhead: McGraw-Hill Education [distributor],; 2008.

[2]. Schilder H. Cleaning and shaping the root canal. Dent Clin North Am. 1974 Apr;18(2):269-96. Pubmed PMID: 4522570.

[3]. Wildey WL, Senia ES, Montgomery S. Another look at root canal instrumentation. Oral Surg Oral Med Oral Pathol. 1992 Oct;74(4):499-507. Pubmed PMID: 1408028.

[4]. Rotstein I, Ingle JI, editors. Ingle's endodontics. PMPH USA; 2019 Jun 1.

[5]. Gutmann JL, Lovdahl PE. Problem-Solving Clinical Techniques in Enlarging and Shaping the Root Canal. Problem Solving in Endodontics. 2011;195-208

[6]. Cunningham CJ, Senia ES. A three-dimensional study of canal curvatures in the mesial roots of mandibular molars. J Endod. 1992 Jun;18(6):294-300. Pubmed PMID: 1402588.

[7]. Walia HM, Brantley WA, Gerstein H. An initial investigation of the bending and torsional properties of Nitinol root canal files. J Endod. 1988 Jul;14(7):346-51. Pubmed PMID: 3251996.

[8]. Pereira ES, Peixoto IF, Viana AC, Oliveira II, Gonzalez BM, Buono VT, et al. Physical and mechanical properties of a thermomechanically treated NiTi wire used in the manufacture of rotary endodontic instruments. Int Endod J. 2012 May;45(5):469-74. Pubmed PMID: 22188417.

[9]. Ebihara A, Yahata Y, Miyara K, Nakano K, Hayashi Y, Suda H. Heat treatment of nickel-titanium rotary endodontic instruments: effects on bending properties and shaping abilities. Int Endod J. 2011 Sep;44(9):843-9. Pubmed PMID: 21564139.

[10]. Singh S, Abdul MSM, Sharma U, Sainudeen S, Jain C, Kalliath JT. An in vitro Comparative Evaluation of Volume of Removed Dentin, Canal Transportation, and Centering Ratio of 2Shape, WaveOne Gold, and ProTaper Gold Files Using Cone-Beam Computed Tomography. J Int Soc Prev Community Dent. 2019 Sep 30;9(5):481-485. Pubmed PMID: 31620381.

[11]. Zhao D, Shen Y, Peng B, Haapasalo M. Micro-computed tomography evaluation of the preparation of mesiobuccal root canals in maxillary first molars with Hyflex CM, Twisted Files, and K3 instruments. J Endod. 2013 Mar;39(3):385-8. Pubmed PMID: 23402512.

[12]. Antony SD, Subramanian AK, Nivedhitha MS, Solete P. Comparative evalu- 
ation of canal transportation, centering ability, and dentin removal between ProTaper Gold, One Curve, and Profit S3: An in vitro study. Journal of Conservative Dentistry. 2020 Nov 1;23(6):632.

[13]. Maitin N, Arunagiri D, Brave D, Maitin SN, Kaushik S, Roy S. An ex vivo comparative analysis on shaping ability of four NiTi rotary endodontic instruments using spiral computed tomography. J Conserv Dent. 2013 May;16(3):219-23. Pubmed PMID: 23833454.

[14]. Govindaraju L, Gurunathan D. Effectiveness of Chewable Tooth Brush in Children-A Prospective Clinical Study. J Clin Diagn Res. 2017 Mar;11(3):ZC31-ZC34. Pubmed PMID: 28511505.

[15]. Christabel A, Anantanarayanan P, Subash P, Soh CL, Ramanathan M, Muthusekhar MR, Narayanan V. Comparison of pterygomaxillary dysjunction with tuberosity separation in isolated Le Fort I osteotomies: a prospective, multi-centre, triple-blind, randomized controlled trial. Int J Oral Maxillofac Surg. 2016 Feb;45(2):180-5. Pubmed PMID: 26338075.

[16]. Soh CL, Narayanan V. Quality of life assessment in patients with dentofacial deformity undergoing orthognathic surgery--a systematic review. Int J Oral Maxillofac Surg. 2013 Aug;42(8):974-80. Pubmed PMID: 23702370. https://pubmed.ncbi.nlm.nih.gov/23702370/

[17]. Mehta M, Deeksha, Tewari D, Gupta G, Awasthi R, Singh H, et al. Oligonucleotide therapy: An emerging focus area for drug delivery in chronic inflammatory respiratory diseases. Chem Biol Interact. 2019 Aug 1;308:206215. Pubmed PMID: 31136735.

[18]. Ezhilarasan D, Apoorva VS, Ashok Vardhan N. Syzygium cumini extract induced reactive oxygen species-mediated apoptosis in human oral squamous carcinoma cells. J Oral Pathol Med. 2019 Feb;48(2):115-121. Pubmed PMID: 30451321

[19]. Campeau PM, Kasperaviciute D, Lu JT, Burrage LC, Kim C, Hori M, et al. The genetic basis of DOORS syndrome: an exome-sequencing study. Lancet Neurol. 2014 Jan;13(1):44-58. Pubmed PMID: 24291220.

[20]. Kumar S, Sneha S. Knowledge and awareness regarding antibiotic prophylaxis for infective endocarditis among undergraduate dental students. Asian Journal of Pharmaceutical and Clinical Research. 2016;154.

[21]. Christabel SL, Gurunathan D. Prevalence of type of frenal attachment and morphology of frenum in children, Chennai, Tamil Nadu. World J Dent. 2015 Oct;6(4):203-7.

[22]. Kumar S, Rahman RE. Knowledge, awareness, and practices regarding biomedical waste management among undergraduate dental students. Asian Journal of Pharmaceutical and Clinical Research. 2017;10(8):341.

[23]. Sridharan G, Ramani P, Patankar S. Serum metabolomics in oral leukoplakia and oral squamous cell carcinoma. J Cancer Res Ther. 2017 JulSep;13(3):556-561. Pubmed PMID: 28862226.

[24]. Ramesh A, Varghese SS, Doraiswamy JN, Malaiappan S. Herbs as an antioxidant arsenal for periodontal diseases. J Intercult Ethnopharmacol. 2016 Jan 27;5(1):92-6. Pubmed PMID: 27069730.

[25]. Thamaraiselvan M, Elavarasu S, Thangakumaran S, Gadagi JS, Arthie T. Comparative clinical evaluation of coronally advanced flap with or without platelet rich fibrin membrane in the treatment of isolated gingival recession. J Indian Soc Periodontol. 2015 Jan-Feb;19(1):66-71. Pubmed PMID: 25810596

[26]. Thangaraj SV, Shyamsundar V, Krishnamurthy A, Ramani P, Ganesan K, Muthuswami M, et al. Molecular Portrait of Oral Tongue Squamous Cell Carcinoma Shown by Integrative Meta-Analysis of Expression Profiles with Validations. PLoS One. 2016 Jun 9;11(6):e0156582. Pubmed PMID: 27280700

[27]. Ponnulakshmi R, Shyamaladevi B, Vijayalakshmi P, Selvaraj J. In silico and in vivo analysis to identify the antidiabetic activity of beta sitosterol in adipose tissue of high fat diet and sucrose induced type- 2 diabetic experimental rats. Toxicol Mech Methods. 2019 May;29(4):276-290. Pubmed PMID: 30461321.

[28]. Ramakrishnan M, Bhurki M. Fluoride, Fluoridated Toothpaste Efficacy And Its Safety In Children-Review. International Journal of Pharmaceutical Research. 2018 Oct 1;10(04):109-14.

[29]. Kandaswamy D, Venkateshbabu N, Porkodi I, Pradeep G. Canal-centering ability: An endodontic challenge. J Conserv Dent. 2009 Jan;12(1):3-9. Pubmed PMID: 20379433.

[30]. Arslan H, Yildiz ED, Gunduz HA, Sumbullu M, Bayrakdar IS, Karatas E, et al. Comparative study of ProTaper gold, reciproc, and ProTaper universal for root canal preparation in severely curved root canals. J Conserv Dent. 2017 Jul-Aug;20(4):222-224. Pubmed PMID: 29259355.

[31]. Iqbal MK, Firic S, Tulcan J, Karabucak B, Kim S. Comparison of apical transportation between ProFile and ProTaper NiTi rotary instruments. Int Endod J. 2004 Jun;37(6):359-64. Pubmed PMID: 15186241.

[32]. Guelzow A, Stamm O, Martus P, Kielbassa AM. Comparative study of six rotary nickel-titanium systems and hand instrumentation for root canal preparation. Int Endod J. 2005 Oct;38(10):743-52. Pubmed PMID: 16164689.

[33]. Yoshimine Y, Ono M, Akamine A. The shaping effects of three nickeltitanium rotary instruments in simulated S-shaped canals. J Endod. 2005 May;31(5):373-5. Pubmed PMID: 15851932.

[34]. Mamede-Neto I, Borges AH, Guedes OA, de Oliveira D, Pedro FL, Estrela C. Root Canal Transportation and Centering Ability of Nickel-Titanium Rotary Instruments in Mandibular Premolars Assessed Using Cone-Beam Computed Tomography. Open Dent J. 2017 Feb 14;11:71-78. Pubmed PMID: 28357000.

[35]. Bhaumik DT, Bhaumik T, Roy M, Das UK, Dutta K. Evaluation of Apical Transportation And Centering Ability of Three Different NITI Endodontic Files- A Comparative In Vitro CBCT Study. IOSR Journal of Dental and Medical Sciences. 2017;16:16-21

[36]. Kishore A, Gurtu A, Bansal R, Singhal A, Mohan S, Mehrotra A. Comparison of canal transportation and centering ability of Twisted Files, HyFlex controlled memory, and Wave One using computed tomography scan: An in vitro study. J Conserv Dent. 2017 May-Jun;20(3):161-165. Pubmed PMID: 29279618.

[37]. Vijayashree Priyadharsini J. In silico validation of the non-antibiotic drugs acetaminophen and ibuprofen as antibacterial agents against red complex pathogens. J Periodontol. 2019 Dec;90(12):1441-1448. Pubmed PMID: 31257588.

[38]. J PC, Marimuthu T, C K, Devadoss P, Kumar SM. Prevalence and measurement of anterior loop of the mandibular canal using CBCT: A cross sectional study. Clin Implant Dent Relat Res. 2018 Aug;20(4):531-534. Pubmed PMID: 29624863

[39]. Ramesh A, Varghese S, Jayakumar ND, Malaiappan S. Comparative estimation of sulfiredoxin levels between chronic periodontitis and healthy patients - A case-control study. J Periodontol. 2018 Oct;89(10):1241-1248. Pubmed PMID: 30044495.

[40]. Ramadurai N, Gurunathan D, Samuel AV, Subramanian E, Rodrigues SJL. Effectiveness of 2\% Articaine as an anesthetic agent in children: randomized controlled trial. Clin Oral Investig. 2019 Sep;23(9):3543-3550. Pubmed PMID: 30552590.

[41]. Sridharan G, Ramani P, Patankar S, Vijayaraghavan R. Evaluation of salivary metabolomics in oral leukoplakia and oral squamous cell carcinoma. J Oral Pathol Med. 2019 Apr;48(4):299-306. Pubmed PMID: 30714209.

[42]. Mathew MG, Samuel SR, Soni AJ, Roopa KB. Evaluation of adhesion of Streptococcus mutans, plaque accumulation on zirconia and stainless steel crowns, and surrounding gingival inflammation in primary molars: randomized controlled trial. Clin Oral Investig. 2020 Sep;24(9):3275-3280. Pubmed PMID: 31955271.

[43]. Samuel SR. Can 5-year-olds sensibly self-report the impact of developmental enamel defects on their quality of life? Int J Paediatr Dent. 2021 Mar;31(2):285-286. Pubmed PMID: 32416620.

[44]. R H, Ramani P, Ramanathan A, R JM, S G, Ramasubramanian A, et al. CYP2 C9 polymorphism among patients with oral squamous cell carcinoma and its role in altering the metabolism of benzo[a]pyrene. Oral Surg Oral Med Oral Pathol Oral Radiol. 2020 Sep;130(3):306-312. Pubmed PMID: 32773350 .

[45]. Chandrasekar R, Chandrasekhar S, Sundari KKS, Ravi P. Development and validation of a formula for objective assessment of cervical vertebral bone age. Prog Orthod. 2020 Oct 12;21(1):38. Pubmed PMID: 33043408.

[46]. Vijayashree Priyadharsini J, Smiline Girija AS, Paramasivam A. In silico analysis of virulence genes in an emerging dental pathogen A. baumanni and related species. Arch Oral Biol. 2018 Oct;94:93-98. Pubmed PMID: 30015217. 